\title{
A születési sorrend hatása a nem kognitív készségekre - avagy hányadikként érdemes születnünk, ha vezetői pályára készülünk? ${ }^{1}$
}

\author{
JÁNOSY ORSOLYA ${ }^{2}$
}

Gyakran tapasztaljuk, hogy az azonos családban felnővő testvérek személyisége teljesen eltér egymástól, pedig szüleik ugyanabban a családi környezetben, megegyező elvek és értékrend mentén nevelik őket. A közvélekedés szerint a legidősebb testvér általában vezető szerephez jut családon belül, ő szolgál viselkedési mintaként kisebb testvérei számára. A legkisebbek gyakran dacosak, akaratosak, hiszen meg kell küzdeniük a szülői figyelemért, az érvényesülésért, ugyanakkor sokszor túlkényeztetettek is. A középső gyerekek talán a legalkalmazkodóbbak, hiszen ők szinte egész gyermekkorukat testvéreik „szorításában”, kisebb és nagyobb testvéreikhez folyamatosan alkalmazkodva élik.

Alátámasztható-e tudományos érvekkel a közvélekedés? Milyen tényezők alakítják az ember személyiségét? Mely személyiségjegyek segítik elő a szakmai sikereket? Hatással van-e a születési sorrend a személyiségre, a kognitív készségekre, illetve a nem kognitív, másnéven szociális-érzelmi készségeinkre (Fazekas 2017)? Van-e összefüggés a születési sorrend és a vezetői készségek kialakulása között, azaz hányadikként született gyermekből lesz felnőttként leginkább vezető?

Már 1927-ben Alfred Adler pszichológus vizsgálta a születési sorrend bizonyos személyiségjegyekre gyakorolt hatását (Adler 1927). Kutatásaiban úgy találta, hogy a legidősebb gyermek vágyik leginkább hatalomra, a legfiatalabb gyermek gyakran túlféltett és kevésbé önálló, mint testvérei, míg a középső testvér ambiciózus és versenyszellemü.

Sulloway evolúciós elmélete szerint a gyermek személyiségére a családi környezet gyakorolja a legnagyobb hatást, melyben a testvérek különböző stratégiák mentén versengenek a „véges”, korlátozottan rendelkezésre álló szülői figyelemért és szeretetért (Sulloway 1996). Az elsőszülött felelőségteljes, ő az, aki leginkább pró-

${ }^{1}$ Black, S. E. - Grönqvist, E. - Öckert, B. (2017): Born to lead? The effect of birth order on non-cognitive abilities. The Review of Economics and Statistics, MIT Press, vol. 100(2), 274-286.

${ }^{2}$ Doktorandusz, Debreceni Egyetem Humán Tudományok Doktori Iskola Szociológia és Társadalompolitika Doktori Program. 


\section{OLVASS FELESLEGESET!}

bál megfelelni a szülői elvárásoknak, míg a kisebbek lezserebbek, közvetlenebbek és barátságosabbak, megpróbálják új viselkedésmintákkal megkülönböztetni magukat testvéreiktől, találékonyan kitölteni a még meglévő „réseket”, szerepeket a családon belül.

Bár korábban már számos kutatás foglalkozott a születési sorrend személyiségre gyakorolt hatásával, egyértelmű összefüggést az elérhető szűk adatbázisok miatt eddig nem sikerült kimutatni (Ernst - Angst 1983, Sulloway 1995, 1996). Az elmúlt évtizedben több kutató is vizsgálta az elsőszülött gyerekek személyiségjegyeit, és megállapították, hogy az idősebb testvéreknek általában jobbak az iskolai eredményeik, magasabb IQ-val, majd később magasabb jövedelemmel rendelkeznek és egészségesebb életmódot is folytatnak fiatalabb testvéreiknél (Barclay 2015, Black Devereux - Salvanes 2005, 2011, Kristensen - Bjerkedal 2007, Kantarevich - Mechoulan 2006).

A jelen tanulmányban bemutatott svéd kutatás újszerűségét a kiterjedt adatbázis biztosította. A kutatáshoz három jelentős adatbázis adatait használhatták fel és hasonlíthatták össze a szerzők. Az elemzések alapjául a svéd népességnyilvántartási rendszer adatai, a sorkatonai szolgálatra jelentkező újoncok személyiségtesztjei és a Svéd Statisztikai Hivatal foglalkoztatási adatai szolgáltak.

A Svéd Statisztikai Hivatal népességnyilvántartásában minden 1932 után Svédországban született személy születési és családi adatai (biológiai vagy nevelőszülők, testvérek) megtalálhatók. Ebből az adatbázisból állapították meg a vizsgált testvérek családon belüli helyzetét. A testvérek születési sorrendjénél az anyai ágat vették figyelembe.

A népességnyilvántartási adatokat kombinálták a Svédországban sorkatonai szolgálatra bevonuló fiatal, 18 éves férfiak pszichológia alkalmassági tesztjeinek eredményeivel. Mivel Svédországban a férfiak számára 2010-ig kötelező volt a sorkatonai szolgálat és a besorozás alól csak a fogyatékkal élők, illetve mentális problémákkal küzdők mentesültek, az adatbázisban az 1952 és 1982 között született férfiak 85\%-ának személyiségtesztje rendelkezésre áll. A 20-30 perces pszichológusok által készített interjúk az újoncok nem-kognitív készségeit egy 1-9 skálán értékelték, elsősorban azt vizsgálták, hogy a katonák alkalmasak-e fegyveres szolgálatra, hogyan viselik a stresszt, és képesek-e csapatban együttmüködni társaikkal. A vizsgálatok kiegészültek a kognitív (logikai, verbális, vizuális és térbeli) készségeket mérő feleletválasztós tesztekkel, amelyek eredményeit szintén 1-9 skálán értékelték. A tesztek apróbb módosításokon estek át 1980-ban, 1994-ben és 2000-ben.

A foglalkoztatási adatok 1996 és 2009 között állnak rendelkezésre. Az adatbázisban a teljes közszféra, valamint a magánszektor 500 fő felett foglalkoztató vállalatainál munkaviszonyban lévő, 16-74 év közötti alkalmazottak adatai szerepelnek. A munkavállalók pozícióját és jövedelmi viszonyait 45 éves korukban vizsgálták.

A foglalkozásokat 10 nagy csoportra osztották. Egyik ilyen csoportba a menedzsmenttel kapcsolatos munkakörök (a felsővezetőktől a közép- és alsóbb-vezetőkig) 


\section{OLVASS FELESLEGESET!}

tartoznak. A vizsgálati eredmények alapján a munkavállalók 8\%-a dolgozik vezetői pozícióban, 0,6\%-a felsővezető. Egy másik csoportot a kreatív foglalkozást végzők alkották, pl. építészek, tervezők, írók, festők, zenészek, színészek. A korábbi kutatások azt mutatták, hogy bár a kognitív és nem-kognitív készségek egyaránt meghatározó szerepet töltenek be a pályaválasztáskor, a nem-kognitív készségek hangsúlyosabbak a vezető pozícióban dolgozóknál (Lindqvist - Vestman 2011). A korábbi pszichológiai vizsgálatok alapján feltételezték, hogy a kisebb testvérek kreatívabbak, kísérletezőbbek, mint idősebb fivéreik (Sulloway 1995).

A három nagy adatbázis mellett egy kisebb adatbázist is figyelembe vettek a téma elemzésekor, ez az Evaluation-Through-Follow-Up (ETF) néven ismert kutatás, amely az 1967, 1972, 1977, 1982, 1987, 1992 évben született gyerekek 10\%-a esetében, a gyermekek 13 éves korában vizsgálta a szülők gyermeknevelésnek szentelt humántőke-ráfordításait.

A kutatás csak olyan családok adatait vette figyelembe, amelyben minimum két fiú és összesen maximum öt gyermek nevelkedett és kizárta az ikrekkel rendelkező családokat. Mivel a katonai adatbázisban csak a férfiak adatai kerültek rögzítésre, a kutatás kizárólag férfiakra korlátozódik. Az említett feltételeknek 260807 család összesen 564789 fia felelt meg, míg az ETF adatbázis 36799 gyermek adatait tartalmazza.

A kutatás elsősorban arra a kérdésre keresi a választ, hogy a születési sorrend befolyásolja-e az egyén nem-kognitív készségeit; milyen foglalkozások körében mutathatók ki erős nem-kognitív készségek; hányadik gyermekként születnek az erős nem-kognitív készségekkel rendelkezők; illetve az elsőszülöttség önmagában predesztinál-e vezető szerepre.

A vizsgálat ennek megfelelően három eredményváltozóra fókuszál, amelyek az említett adatbázisok alapján: a nem-kognitív, másnéven „BIG FIVE” készségek ${ }^{3}$ (katonai adatbázis); a foglalkozások (foglalkoztatási adatbázis); illetve a szülői humán tőke ráfordítás mértéke (ETF adatbázis).

A születési sorrend vizsgálatának eredményei azt mutatják, hogy a nem-kognitív készségek gyengülnek a születési sorrend előrehaladtával, azaz a másodszülöttek szociális-érzelmi készségei gyengébbek, mint elsőszülött testvéreiké, de erősebbek, mint a harmadszülötteké.

A különböző foglalkozási csoportok tagjainak kognitív és nem kognitív készségeket mérő teszteredményeiből kitűnik, hogy a vezetői csoportba sorolt személyek mindkét teszttípusban jobbnak bizonyultak a többi csoporthoz képest, valamint a nem-kognitív készségek terén is jelentős fölényük mutatkozott még a kreatív csoportba tartozókkal szemben is. Az adatokból az is kitűnik, hogy a később született

${ }^{3}$ A BIG FIVE készségek alatt a szakirodalom öt fő személyiségjegy csoportot ért, amelyek a lelkiismeretesség, a konszenzuskészség, a kiegyensúlyozottság, az újdonságok iránti nyitottság és az extrovertáltság (Fazekas 2018). 


\section{OLVASS FELESLEGESET!}

gyermekek esetében egyre nő az önfoglalkoztatás esélye, ők gyakrabban dolgoznak saját vállalkozásban, mint idősebb testvéreik. A kutatás ezt elsősorban úgy értelmezi, hogy a később született gyerekeknek rosszabbak a munkaerőpiaci kilátásaik és így rákényszerülnek arra, hogy saját vállalkozásban helyezkedjenek el.

A kora gyermekkori élmények is jelentősen befolyásolják a kognitív és szociális-érzelmi készségek fejlődését. Az ETF adatok jól tükrözik a szülői viselkedés változását, a szülő-gyermek kapcsolat átalakulását a családba születő gyermekek létszámának növekedésével. Az elsőszülött gyermek megkapja a szülők teljes figyelmét, de szülei tapasztalatlanabbak és gyakran szigorúbb elvárásokat támasztanak vele szemben. Később a kisebb testvéreknek már osztozniuk kell a szülői figyelmen, a szülői elvárások és nevelési elvek fellazulnak, de már a szülők jelentős tapasztalattal és sokszor jobb anyagi körülményekkel is rendelkeznek, mint korábban. Az egy gyerekre jutó szülői időráfordítás (quality time) a gyermekszám növekedésével azonban jelentősen csökken. A kisebb testvérek átlagosan heti egy órával kevesebb időt szentelnek a tanulásnak és több időt töltenek a tévé, számítógép előtt, mint testvéreik, szüleik is ritkábban tanulnak velük, vagy korrepetálják őket, amely magyarázatul szolgálhat a gyengébb eredményekért. A rivalizálás és a konfliktushelyzetek gyakori elemei a testvérek közötti viszonynak, a konfliktusok főbb okai a tulajdonlás, a személyes tulajdon védelme, a szülők figyelméért folytatott versengés. A gyerekek bár azonos családban nevelkednek, szüleik hozzájuk való viszonya a születési sorrend függvényében más és más, valamint a gyerekek által családon belül betöltött szerepek is különböznek egymástól.

A vizsgálatok során a nem-kognitív készségek összehasonlításakor számos indikátorváltozót vettek figyelembe, amelyek a következők: születési sorrend, azaz a fiúgyermek hányadik fiúként születik a családba; a család összes gyermekének száma; a vizsgált gyermek és az édesanya születési éve; az édesanya kora első gyermeke születésekor; a gyermekek közötti korkülönbség; illetve az anya iskolai végzettsége.

Az eredmények összevetéséből kitűnik, hogy a születési sorrend előrehaladtával a gyermekek nem-kognitív készségei gyengülnek, azaz az elsőszülött fiú készségei erősebbek a másodszülötténél, míg a harmadszülött készségei gyengébbek az idősebb testvéreihez viszonyítva. Az elsőszülöttek érzelmileg stabilabbak, kitartóbbak, kezdeményezőbbek, erősebb társadalmi készségekkel rendelkeznek, jobban készek felelősséget vállalni, mint fiatalabb testvéreik.

A munkavállalói szerepek is eltérést mutatnak: az elsőszülött férfiak 30\%-kal nagyobb valószínűséggel lesznek felsővezetők, mint harmadiknak született fivérük, mivel a vezetői pozíciók erősebb BIG FIVE készségeket feltételeznek.

A személyiségjegyek kialakulásában szerepet játszhat még a családban fennálló nemek aránya, azaz a testvérek között milyen a fiú-lány arány. A később született fiúkat hátrányosabban érinti, ha idősebb fiútestvérei vannak, míg az idősebb lánytestvérek öccsük nem-kognitív készségeit nem gyengítik. 


\section{OLVASS FELESLEGESET!}

A kutatás eredményei tehát megerősítik azt a közvélekedést, hogy az elsőszülött fiúnak van legnagyobb esélye a vezető pozíció elnyerésére, hiszen ő rendelkezik testvérei közül a legerősebb kognitív és nem-kognitív készségekkel, míg cáfolják azon pszichológiai vélekedéseket, mely szerint a később született gyermekek felnőttként érzelmileg stabilabbak, az újdonságok iránt fogékonyabbak és társas készségeik is erősebbek lennének.

\section{Irodalom}

Adler, A. (1928): Characteristics of the first, second, and third child. Children 3, 1452.

Barclay, K. J. (2015): A within-family analysis of birth order and intelligence using population conscription data on Swedish men. Intelligence 49, 134-143.

Black, S. E. - Devereux P. J. - Salvanes K. G. (2005): The more the merrier? The effect of family size and birth order on children's education. The Quarterly Journal of Economics, 669-700.

Black, S. E. - Devereux, P. J. - Salvanes, K. G. (2011): Older and wiser? Birth order and IQ of young men. CESifo Economic Studies 57, 103-120.

Black, S. E. - Grönqvist, E. - Öckert, B. (2017): Born to lead? The effect of birth order on non-cognitive abilities. The Review of Economics and Statistics, MIT Press, vol. 100(2): 274-286.

Ernst, C. - Angst, J. (1983): Birth order: Its influence on personality. New York: Springer Verlag.

Fazekas K. (2017): Nem kognitív készségek kereslete és kínálata a munkaerőpiacon. Budapest Munkagazdaságtani Füzetek

http://econ.core.hu/file/download/bwp/bwp1709.pdf utolsó letöltés: 2018. 12. 02 .

Fazekas K. (2018): Nem kognitív készségek hiánya a munkaerőpiacon. Magyar Tudomány 179/1. 24-36.

http://real.mtak.hu/80471/1/MaTud20181_3_u.pdf utolsó letöltés: 2018. 12. 02.

Kanterevic, J. - Mechoulan S. (2006): Birth order, educational attainment, and earnings an investigation using the PSID. Journal of Human Resources 41, 755-777.

Kristensen, P. - Bjerkedal, T. (2007): Explaining the relation between birth order and intelligence. Science 316, 1717. 


\section{OLVASS FELESLEGESET!}

Lindqvist, E. - Vestman, R. (2011): The Labour Market Returns to Cognitive and Noncognitive Ability: Evidence from the Swedish Enlistment. American Economic Journal: Applied Economics 3, 101-128.

Sulloway, F. J. (1995): Birth order and evolutionary psychology: A meta-analytic overview. Psychological Inquiry 6, 75-80.

Sulloway, F. J. (1996): Born to rebel: Birth order family dynamics, and creative lives. New York, Pantheon. 